\title{
FINANCING INVESTMENT IN INDUSTRIAL TECHNOLOGICAL INNOVATION
}

\author{
André Cutrim Carvalho ${ }^{1}$ \\ David Ferreira Carvalho ${ }^{2}$
}

\begin{abstract}
In 1982, Schumpeter outlines his theory of real competition in which technological innovation is not only a competitive weapon to conquer new markets, but also mainly responsible for structural changes through the process of creative destruction. He has in mind that the capitalist economy is, above all, an evolutionary economics in which technological innovations, such as new forms of combinations of means of production, are inducers of capitalist economic development. In this context, the economic terms of employment of productive resources, drawn from conventional uses coming up with one point in new uses hitherto untested in practice, able to produce new products and production processes through new combinations of material and productive forces, that is, technological innovations, ie economic development in the Schumpeterian sense is a distinct phenomenon and entirely foreign to what can be observed in the circular flow or in the tendency to equilibrium, since starting on producer and not the consumer, despite its importance. In this context, the main objective of this article is to highlight the specificity of funding investments in technological innovations.
\end{abstract}

Keywords: technological innovation, economic development, investment financing.

\section{FINANCIAMENTO DE INVESTIMENTO EM INOVAÇÃO TECNOLÓGICA INDUSTRIAL}

RESUMO: No ano de 1982, Schumpeter esboça a sua teoria da concorrência real, na qual a inovação tecnológica não é apenas uma arma da concorrência para conquistar novos mercados, mas também a principal responsável pelas mudanças estruturais por meio do processo da destruição criadora. Ele tem em mente que a economia capitalista é, antes de tudo, uma economia evolucionária na qual as inovações tecnológicas, como novas formas de combinações de meios de produção, são indutoras do desenvolvimento econômico capitalista. Nesse contexto, o desenvolvimento econômico diz respeito ao emprego de meios produtivos, retirados dos usos convencionais que vinham tendo até um dado momento, em novos usos, não testados até então na prática, capazes de produzir novos produtos e processos de produção por meio de novas combinações de materiais e forças produtivas, isto é, de inovações tecnológicas, ou seja, o desenvolvimento econômico no sentido schumpeteriano é um fenômeno distinto e inteiramente estranho ao que pode ser observado no fluxo circular ou na tendência para o equilíbrio, já que têm início no produtor e não no consumidor, apesar da sua importância. Nesse contexto, o objetivo fundamental deste artigo é destacar a especificidade do financiamento do investimento em inovações tecnológicas.

Palavras-chaves: inovação tecnológica, desenvolvimento econômico, financiamento do investimento.

\footnotetext{
${ }^{1}$ Professor-pesquisador da Faculdade de Economia da Universidade Federal do Pará - FACECON/UFPA. Email: andrecc83@gmail.com.

${ }^{2}$ Professor-pesquisador da Faculdade de Economia e do Mestrado em Economia do Desenvolvimento Regional da Universidade Federal do Pará - FACECON/PPGE/UFPA. E-mail: david.fcarvalho@yahoo.com.br.
}

Recebido em 15/08/2013

Aceito em 24/10/2013 


\section{INTRODUCTION}

The process of industrial development can be historically observed when separating the phenomenon of expansion of industry in general growth of certain industries that carry natural and technological innovations that are part of this process. If we look at the technological changes that occurred throughout the history of competitive capitalism, it is possible to identify a class of cases in which both companies as innovative natural imitators entire industries were attracted by effective demand created by new products or production processes of the company that pioneered innovative with the improvements and large-scale production, not only able to sell their innovations to lower prices, but also creates a market for mass consumption for widespread innovation that allows endogenous growth automatically.

This additional demand to the circular flow, as noted by Schumpeter (1971, p. 28-29), originated as a secondary phenomenon, a primary change in any single industry - in the phase of the competitive textile industry came first and then industry pig iron and the steam engine, the shipbuilding and steam railway, electricity industry and heavy chemical industry later that does not follow the trajectory of expansion old, but instead creates a new growth trajectory that promotes a cyclical wave of economic development, sui generis, from the processes of creation, improvement and diffusion of new products or production methods loaded by singular industries innovative, technologically advanced, passing to manufacture on a large scale technological innovation creates new markets with high growth potential.

The production technology is actually determined by the economic system; technology creates and develops new products and production methods demanded for consumers who want and have purchasing money to accomplish your needs. The economic logic, as expected, trumps technology. This means that the invention (of new products or new production methods) is a product developed by engineering technique, which is based on the findings and principles by legacies and biological sciences. But innovation is the result of the initiative of the innovative entrepreneur who takes good economic decision, with adequate financial support of the banker, to launch a new product or a new production method in the expectation of success in terms of monopoly profit, insofar where innovation creates a new market.

Nevertheless, this expectation of the employer in respect of the unknown future is subject to the time of its decision, the risks and uncertainty that could result in radical success or failure of the venture. Either way, the decision-making fund investment for a technological innovation is a crucial decision in the environment of radical uncertainty to the financier - the 
Revista Economia e Desenvolvimento, v. 25, n. 2, 2013.

banker-capitalist - and the innovative entrepreneur who assumes the burden of doing something that has never been done.

However, the introduction in the economic system of a new production method requires investment financing of industrial technology innovation by the capitalist owner of purchasing power and interested in transferring it to the innovative entrepreneur. In a capitalist economy, the banker is essential not only for being the possessor of the purchasing power of general equivalence with the potential to make the remuneration of the factors of production, purchase of property and the payment of debts, but also because the transfer of the purchasing power by the banker to the innovative entrepreneur allows it to have access to the means of production and materials necessary to perform its technological innovation.

The need for funding is not only for investments in industrial innovations, especially for new long-term investments in machinery, capital equipment, transportation, machinery installations and equipment capital and civil buildings, but also for research and development in the strict sense, and resources needed to finance new activities to train qualified personnel in specialized training centers, universities and research institutions.

While aware of that need, this article will not discuss the funding in education, research and development pertinent to national innovation system defined as an integrated body of public and private institutions in the areas that contribute to macroeconomic and micro generation, development and diffusion of innovations technological highlights such as Lundvall (1995). The financing of investments in industrial innovations should affect both the temporality between the time of decision making and when the project is funded by the innovative banker, but also when the innovative design turns into reality when the new venture begins industrial-scale production of new products or new processes.

The purpose of this article is to address the issue not only technological innovation as the main driver responsible for the evolutionary process of modern capitalism, but mainly discuss the importance of funding the investments in technological innovation. For this, we tried to organize this article into three basic section: 1) discusses the meaning Schumpeterian economic development as a process of creative change through technological innovations; 2) we discuss the differences between innovative individual entrepreneur, the phase of competitive capitalism, and business corporations (business groups with common interests) under Schumpeterian competition in oligopolistic capitalism; 3) finally, discusses the issue of financing the investments of innovations technology, in terms of market and hierarchies, on the procedures of venture capital for small businesses and large corporations. 


\section{ECONOMIC DEVELOPMENT AND TECHNOLOGICAL INNOVATIONS}

Schumpeter (1982) introduces the concept of economic development, different from that used by structuralist economists - for which economic development comprises a historical process of economic growth with deep structural changes that lead to improved income distribution and social welfare - and the neoclassical economists who treat economic growth, which for them is intertwined with economic development, being driven by technical progress through the market.

Produce in capitalist society means combining material and productive forces that are available and the scope of the entrepreneur. Any production method implies, in a way, a specific form of combination of material and productive forces seeking to transform raw materials and secondary raw end products that can be used, depending on your destination, as well as capital or well of consumption. The production coefficients of the input-output matrices, which represent the quantitative relations of production goods per unit of product, are a feature of the combination of materials (inputs) and the productive forces (labor, labor, capital, land and entrepreneur) for performing the method of production (technology).

Schumpeter (1982, p. 41-42) part of the circular flow - a supposed economic system in which the flow of goods and the corresponding cash flows in the opposite direction, forming a set of flows and even repetitive continuous adaptive - which characterizes the steady state. The economic system stationary or static equilibrium and does not produce or reproduce discontinuous movements themselves Schumpeterian economic development.

For economic development, Schumpeter (1982, p. 47) only understands the changes in the economic system that are not exogenous, but those that arise endogenously and own initiative entrepreneurs unusual. Economic development is defined by Schumpeter in carrying out new combinations of materials and productive forces. Produce other goods or the same goods with different methods means combining differently materials and the productive forces.

For Schumpeter (1982, p. 48) the creative changes, and not adaptive changes, do not usually start in the sphere of consumer needs - although not denied the nexus that the production is always made to meet the needs of consumers - but in the sphere of production and marketing of the capitalist economy. It is the producer who, as a rule, begins the process of economic change, and consumers in general are, so to speak, educated, ie taught to demand and use new goods that differ in one aspect or another of those goods had the habit of using. 
Revista Economia e Desenvolvimento, v. 25, n. 2, 2013.

To the extent that new combinations can, over time, to originate from old combinations through minor adjustments, there are certainly economic changes, possibly for economic growth, but not a new phenomenon nor discontinuous economic development in the sense defined by Schumpeter. Only new combinations appear discontinuously are characteristic of economic development defined by the completion of new combinations of materials and productive forces.

Schumpeter (1971, p. 30) terms of economic development, in essence, the employment of productive resources, drawn from conventional uses coming up with one point in new uses hitherto untested in practice, able to produce new products and production processes through new combinations of materials and productive forces, which Schumpeter called innovations. This concept of innovation Schumpeter (1982, p. 48) has 5 modes, namely: 1) Product innovation: the introduction of a new product, ie, a new well that consumers are not accustomed or a well of a new quality. In both cases the result is the creation of a new market; 2) Innovation in the production process: introduction of new production method, ie a method that has not been tried in their own branch of the manufacturing industry, which method do not necessarily need to be based on a new scientific discovery, and may consist also a new way of handling or transporting commercial goods; 3) Opening of a new market: the creation of a new market in which the particular branch of a manufacturing industry of the country in question has not yet entered either this new market has ever existed before or not; 4) conquest of a new source of supply: the conquest of a new source of supply of raw materials or semi-manufactured goods, again irrespective of whether this source already existed or had to be created; and 5) Organizational innovation: creating a new business organization of any industry through the creation of a monopoly position or the fragmentation of a monopoly position.

There are 3 essential conditions inherent to the achievement of technological and organizational innovations: 1) the general technological or organizational innovations embodied arise with the creation of new companies that do not arise from the old, but it begins to produce at his side. Schumpeter (1982, p. 48-50) uses the example to explain this fact: "in general is not the owner of the diligence which builds railways"; 2) the realization of technological or organizational innovations simply means the different job (new combination) providing media production in existing economic system; 3) the realization of innovations requires the creation of credit by banks, ie, the effective supply of purchasing power created by bankers to entrepreneurs. Innovation is a feat of will more than intellectual innovator. 
This innovative entrepreneur leadership manifested by difficulties he has to face and overcome in the face of resistance and uncertainties that are connected with the realization of what (innovation) which has never been done before, that is, something that is only accessible and attractive to a leadership different and rare man of unusual business. Overcoming all these difficulties related to technical change and economic industrial development is the social function of the innovative entrepreneur.

\subsection{Entrepreneurship and innovative business function}

The enterprise must be understood as the realization of new combinations, ie, the creation of technological and organizational innovations that end up creating a new production company and a new market which did not exist in the economic system. Schumpeter (1982) calls the entrepreneur-innovators those individuals whose social function in the capitalist system is to realize in practice innovations. These two concepts are both broader and narrower than are commonly employed by businessmen. But large because in the first place, entrepreneurs are not restricted to businessmen "independent" in a market economy that, in general, are so designated, but all that actually fulfill this social function, even if they are employees' dependents a publicly held corporation, that is, as executive managers or as members of the board, or even if your actual power (real) to perform or enforce the entrepreneurial function has other grounds can influence decision making corporations, such as those shareholders who have control of most of the common shares.

\subsubsection{Function innovative entrepreneur and capitalist}

We must distinguish, in Schumpeter's model, the figure of the capitalist entrepreneur. The entrepreneur is the agent who, though lacking the capital or of assets and legacy, has the function of combining differently materials and production factors. Schumpeter (1982, p. 6566) recalls that in the early history of the English industrial capitalism, the entrepreneur that time was called "captain of industry" because they exercised both owner role and the function of management. Thus, someone is only when innovative entrepreneur can effectively carry out new combinations, and loses that character as soon as it is installed your new business and will dedicate itself will drive it, like other entrepreneurs manage their business.

The role of innovative entrepreneur in capitalist society is to reform or revolutionize the pattern of production technology exploiting an invention or, more typically, a possibility not yet attempted a new merchandise, produce a commodity existing in a new way to discover 
Revista Economia e Desenvolvimento, v. 25, n. 2, 2013.

and explore new economic frontier (mineral or agricultural) creating a new market for new products or features or even existing, to organize an industry and so on.

\subsubsection{Economic leadership of the innovative entrepreneur}

Perform activities of innovations is very hard and is a special social function of innovative businessman. This is so because, first, these activities are outside the routine activities that are themselves businessmen common, and, secondly, because the economic environment resists new practice in many ways, which vary from simple refusal banks to finance technological innovation or buy something new to the physical or psychological attack against the leadership of the business man who tries to introduce a technological innovation.

To accomplish the introduction of an innovation, the entrepreneur needs to convince himself and convince the banker to finance their innovation. The innovative entrepreneur is left with the conduct of a leader with distinct characteristics of political leaders, military, artistic, scientists and managers. The leadership of the innovative entrepreneur comes when he decides to introduce an innovation in the economic system. Such economic leadership is different from leadership's technical and scientific inventor. The scientific discoveries and inventions are economically irrelevant, as they do not start in the economic system by the innovative entrepreneur. While entrepreneurs may be inventors - as can also be capitalists are not inventors by nature of their business function but by coincidence. The innovations, whose realization depends on the innovative entrepreneur, need not necessarily be inventions.

The innovative entrepreneur holds a different kind of leadership in capitalism due, on the one hand, the difficult decision to launch an innovation in the economic system - against all kinds of resistance - for which there is still a market, and on the other hand, because the success with innovation, by obtaining temporary windfall, opens new and great business opportunities never seen before, which ends up attracting entrepreneurs imitators about competition these go gradually being reduced and even contribute to the end of extra profits arising from innovation.

The decision to introduce an innovation of a product or production process is a radical decision under uncertainty because in this case, the expected long-term earnings expected in the future will depend on the success or failure of innovation creating your market. Even when there is strong resistance groups threatened by innovation, difficulties in finding the necessary cooperation of the bankers to finance innovation and, ultimately, to conquer difficulties consumers to innovation, these obstacles can be overcome only by an economic leadership with a special type of function in contrast to a mere difference in social standing. 
The Schumpeterian entrepreneur is a special kind of leadership we have with primary motivation, besides the extraordinary profit expected, the desire to win, that is, the impulse to fight, compete to prove themselves superior to their rivals, fighting to succeed in its name, not its fruits, but of their own success. The decision and the action of economic agents who assume a leadership business become close to those competitions that occur in certain sports activities. In economic activities, the agents also develop financial and economic competitions whose strategies used by players competitors to win are the innovations, powerful economic weapons of creative destruction and no more disputes over prices and costs. For the innovative entrepreneur, profit extra money is a welcome result, but it is the satisfaction of the success achieved by the introduction of innovation that provides for the innovative entrepreneur the joy of creating something new, to make new things and to exercise power.

\subsection{Innovative entrepreneur and business profit}

The business activity of the leader, resulting in the realization of a new combination, can be conceived as a means of production. In this sense, the leadership role of the entrepreneur can be considered as a factor of production is important because it realizes that the new combination of production factors with the original to introduce innovation. Once the entrepreneur has no competitor, when innovation creates a new market, the determination of monopoly price is processed according to the principles of the theory of monopoly. The creation of a corporation carries profit foundation of the business and investment returns: the first is the value of the monopoly and the latter is just the yield condition of monopoly. For Schumpeter (1982,p. 102-105), business profit is the expression of the monetary value of what the innovative entrepreneur contributed to the production of a product or process innovation, and thus a new market that has not existed.

The monopoly profit, as an alternative source of self-financing, derives from the fact that, since the innovative entrepreneur has no competitor when new products or production process, appear for the first time, the determination of price and profit margin monopoly takes place entirely or within certain limits in accordance with the principles of the cost price and the monopoly (or oligopoly). This is the advantage of an organizational innovation type trust (public company) in which the creation of the organization is a monopoly business act and its primary "product" is the monopoly profit.

For Schumpeter (1982, p. 102-105), the profit of the foundation of the corporation of a big deal and the return of invested capital are different ways to profit: the first is the monetary 
Revista Economia e Desenvolvimento, v. 25, n. 2, 2013.

value due to the monopoly itself (trust) - it certainly does not fear the time of its established competitors or potential - and the latter is the expected return of the condition of the monopoly that is given by technological innovation introduced that created the new market.

\section{BUSINESS CORPORATIONS AND SCHUMPETERIAN COMPETITION}

Schumpeter (1982), when he wrote his book "The Theory of Economic Development" at the beginning of the twentieth century, was the figure of the innovative entrepreneur as an individual with intuition and rationality sufficient to promote technological innovation. When Schumpeter (1984) writes his other major work, "Capitalism, Socialism and Demography", even in the middle of the twentieth century, he is living in a new economic environment in which competition was giving by corporations in business structures oligopolistic market. The illusion of perfect competition is only the dream of neoclassical economists.

The facts from the early history of monopoly capitalism does not lead us to the doors of small individual firms working in conditions of relatively free competition, but virtually to large corporations - which, as in the case of agricultural machinery industries, are also responsible for part of the introduction of technological innovations in the competitive sector where agriculture - on which they rest today the creation of improved standard of living compared to competitive phase of capitalism. Innovation in competitive capitalism was always built with the creation of a new company.

\subsection{Business corporations industrial}

In oligopolistic capitalism everything is different. In this case, according to Schumpeter (1979, p. 36-37), innovations in general no longer succeeds only from the creation of new companies, because the innovations began to be created within the research and development departments of large corporations largely independently of the old typical entrepreneur's innovative competitive capitalism. In oligopolistic capitalism, technological progress becomes increasingly automated, increasingly impersonal and less dependent on the leadership of the heroic man of unusual business and individual initiative.

Penrose (2006, p. 61-65) defines the firm as an administrative unit possessing a set of productive resources whose provision between different uses and over time is determined by administrative decisions of management. The size of a firm production can be scaled by the ratio of productive resources it employs. But a large business corporation, beyond those 
elements, performs other activities that go beyond the productive activities, for example, investments in financial assets and technological innovations.

Business corporations are large publicly traded organizations that own most of the capital assets of a national economy. Corporations also collect greatest share of gross income from capital. A portion of the gross income of such corporations is preferentially distributed to the holders of preferred shares in the form of dividends in accordance with the legislation in force. The total net income is retained for new investments for expansion or diversification of production units that form the business corporation as an economic group. Modern corporations often devote a portion of undistributed earnings to finance investments for expansion, diversification and research and development in the search and selection of inventions with the potential of becoming technological innovations.

Business corporations also act as financial institutions have special powers that allow them to collect funds at a large number of other companies and assume debts through the issuance of bonds in the capital market. The structure of gross revenue in the form of monetary cash flows and shareholders' equity of complete business corporations the ability to leverage these types of business organizations in a corporation. For Minsky (2008, p. 219-246):

The institutional separation of ownership (shareholders) and management
(executive) in large publicly traded business corporations and the consequent
development of financial markets organized and ordered just facilitating the
financing of investments of large corporations. But if access to sources of external
financing on money markets and capital became more feasible, and secondly, the
facility to operate with generators debt financing in these two markets can
sometimes contribute greatly to transform from one time to another a financial
system in a robust financial system weakened to the point of triggering a process of
financial instability in the economy as a whole.

The large corporations and money markets and capital are important institutions created by oligopolistic capitalism of today. In the absence of exchanges there is no way seek often the revaluation of investments through the prices of shares of a corporation. The publicly traded business corporations may incur debt through bond issues or actions that may facilitate external financing of investments through the stock exchange, and not only as agents of the owners (shareholders) through bank loans.

It is in this sense that business corporations have competitive advantages not only facilitated by access to external sources of financing industrial investments in capital assets or investments in financial assets in the capital markets, but also the financial position resulting from the assessment carried out by stock market almost every day on stock prices that serve 
Revista Economia e Desenvolvimento, v. 25, n. 2, 2013.

as indicators of the financial health of corporations to shareholders rentiers and speculators who can review or not their applications.

\subsection{Industrial Competitiveness Schumpeterian}

In an environment oligopolistic capitalism, large industrial corporations have to "gun" the main technological innovation. Nelson (2006, p. 143-144) points out that this new pattern of competition between corporations, through technological innovations, is known in the economic literature by Schumpeterian competition. The industrial Schumpeterian competition is part of a dynamic and evolutionary perspective of the functioning of the capitalist economy.

To Possas (2002, p. 419-421), the competition-based industrial innovation has as main feature the relentless pursuit of differentiation of their products on the part of economic agents through competitive strategies, always seeking competitive advantages capable allow obtaining profits of monopolies transient, ie, temporary extra profits. Moreover, according to Nelson (2006, p. 227-232), large corporations are different in size, organizational structure, competitive strategies and domain extension of the national and international market.

The Business corporations do not seek confrontation competitive only based on product differentiation or production methods, but also seek to expand and diversify its activities into new economic spaces, industrial, commercial and financial. Business corporations are structurally different from individual companies or family limited liability companies. These private companies have serious limitations in their ability to cope with competitive via concentration and centralization of capital, because they are restricted competition mainly through reduction of price margins and costs of their products. The process of creative destruction is the essential fact of the capitalist system and that's where all companies have to live. However, it is usual neoclassical economists examine, from a certain point in time, the behavior of an oligopolistic industry (an industry that consists of a few large firms) and observe the inner dynamics regarding the movements of prices and barriers to entry, but within the strong hypothesis of an eternal stability. Accept data from the momentary situation as if she had not past or future.

Schumpeter (1984) found that competition in oligopolistic structures between large modern corporations established and potential entrants, was given long before the product reaches the market. In fact, the decision to promote modern corporations funding technological research in the search and selection of inventions already part of the process of generating innovations. This relentless pursuit of selection inventions with the potential to 
Financing investment in industrial technological innovation.

turn into something innovations has become routine in research centers of R \& D departments of companies, specialized in the research centers of government and private institutions and the public and private universities.

\subsubsection{The innovative entrepreneur and business corporation that selects innovations}

The innovative entrepreneur typical lost its function over the years, and tends to lose it increasingly in the near future, even if it does not change the economic process in which the business is the main starter of the capitalist machine. This is happening because, on the one hand, the fact that it is now easier than in the past to make things happen outside the familiar routine - innovation itself is now being reduced to routine.

On the other hand, Schumpeter (1984, p. 174) notes that the personality and willpower have increasingly less in environments that have become accustomed to economic changes best exemplified by the incessant stream of new consumer goods and production - and that, rather than resist, accept naturally.It seems that the resistance arising from interests threatened by an innovation in the production process does not die while persisting capitalist order.

It is in this broad sense that Schumpeter (1984, p. 174) states that "economic progress tends to become depersonalized and automated." In fact, with the creation of the department specializing in $\mathrm{R} \& \mathrm{D}$ in the business corporation, the work of teams and committees at research institutions and development $(\mathrm{R} \& \mathrm{D})$ of large corporations, along with the growing closeness of them at universities and research institutes, tend to replace the individual action of the innovative entrepreneur through the process of search and selection inventions with the potential to turn into innovations when so suits a large corporation.

Nevertheless, this does not mean the definitive end of the entrepreneur and innovator nor the exclusive appearance of an innovation as the source always has a large modern enterprise. There are practical examples of how innovation can be generated in a home workshop when it comes to sophisticated inventions in various areas of electronics. Another aspect that must be considered when it comes to creation and diffusion of innovation by any corporation, is the fact that this may delay the launch of its innovation for strategic reasons in the face of the risk of losing the competition to another corporation as its logo technological innovation is introduced into the economic system.

There is a marked difference between the discoveries (invention) conducted in laboratories and research institutions introducing these into the economic system as a technological innovation. Moreover, it should be noted that a researcher-inventor has limitations to found a company and market your invention. These activities involve the transfer of research results and technical-scientific, therefore, a set of standards involving copyright. The research 
departments of corporations and business developments can develop inventions, even before turning into innovations are patented by corporations. Patents are titles of properties of an invention or a new utility model as a tool for protection against imitators.

According to Schumpeter (1984, p. 129-13), large modern companies defend their copyright on certain innovation through patents. There are cases where patents acquired by larger companies were not immediately used, or have not been used in any way. There may be good reasons for this to happen. For example, the patented process may prove ineffective or even the end it may be that the business corporation, which owns the patent, resolve not to allow the immediate implementation on a commercial basis.

Broad pioneering patents could generate conflicts between rivals who, in turn, can lead to patents subsidiaries original patents that have been generating disputes end up in court. Thus, for example, Sen (2001) insists that it is time to change the patent laws that inhibit the diffusion process bioinnovations able to save human lives. There is already a consensus that the amplitude of the property rights of innovations can become a major obstacle to economic and technological development of the underdeveloped countries. Anyway, patents are an instrument of defense of innovative entrepreneurs pioneers against imitators.

These sequences of decisions very often do not take into account, as should the possibility of initial innovation could be replaced by other more efficient. This is a typical process of path dependence in which the first innovation that has created and successfully, as market acceptance, follows a trajectory dependent on previous decisions not necessarily based on some criterion of efficiency ${ }^{3}$. Authors like David (1985, p. 332-337) and Heller (2006, p. 260273) note that this can happen because the market may be stuck to the product (used) first released in a typical process of lock-in.

The growing closeness of modern science with technology has provided various interactive and synergistic effects and positive drivers of economic transformation of inventions into technological innovations. A program of research and development ( R \& D) promoted by a large business corporation can define a technological paradigm. In analogy to the scientific paradigm of Kuhn (1963), Dosi (2006) used the term technological paradigm towards a program of technological research that identifies problems and sets the standard procedures for solving technological problems selected by the researchers based on principles selected,

\footnotetext{
${ }^{3}$ The classic example is the choice of the qwerty keyboard and Dvorak keyboard of typewriters. Although the Dvorak keyboard was more efficient, as the qwerty keyboard was released first and consumers joined their use, manufacturers of typewriters preferred to continue investing in improvements typewriter with the QWERTY keyboard to start over with the typewriter dvorak keyboard.
} 
derived from the natural sciences, and materials technologies. Just as the scientific paradigm was the fulfillment of a promise of researcher-inventor of finding a solution to a problem that all scientists are involved, this procedure also applies to the technological paradigm. To Dosi (2006, p. 40-51), technical progress, therefore, has evolved from technological paradigm established by the technical and scientific community of researchers.

Investment financing a research program to solve a technological problem that requires a technological trajectory has already presented some practical results that can motivate investment funding needed to continue the program of technological research. But it can also happen that the technological paradigm is surprised by the introduction of another technological innovation that prevents the continued funding of investments for technological trajectory whose program of research and development should be stopped because it became obsolete.

Even a primary technological innovation is always subject to successful incorporation of minor enhancements to improve the practical performance. The concept of technological paradigm is useful in this regard because it allows the routine analysis of rules and heuristics in the process of creation of small innovations resulting from the processes of learning by doing and learning by using. Possas (1999, p. 85-98) draws attention to the fact that, in addition to cost advantages and product differentiation, it is necessary to think of the attributes associated with appropriability, cumulative, technological opportunity, interactivity and flexibility.

\subsubsection{Investment in technological innovations under uncertainty}

The investment decisions in industrial innovations involve long-term expectations about the possibility of new combinations come to be economically viable in view of the potential future economic demand, and financially feasible. However, to enable any technological innovation, we must anticipate a third factor which is exactly the commitment of funds from external financing. Therefore, the financing of investment in technological innovation in the broad sense, involves a high level of uncertainty and risk, because the monetary profit expected profit depends on the banker's monopoly provided by the future development of the innovative entrepreneur.

But the reality is that there is no guarantee on the part of the entrepreneur as the innovator's expected profit lending bank when it comes to crucial decision of investing in an environment of radical uncertainty in the sense of Keynes. For all that, the long-term expectations about the future course of technological innovations are an important, though often neglected, to the 
Revista Economia e Desenvolvimento, v. 25, n. 2, 2013.

extent that risks and uncertainties are crucial when it comes to crucial decisions of investment financing of innovative businessman.

Rosenberg (1927, p. 164) points out that the decisions to adopt innovations are elements of expectations that have not received sufficient attention, nor were explored in a systematic way, as much as possible to illuminate the process of technological diffusion. As we know, the theory of capitalist economic development of Schumpeter (1982) part of the circular flow of economic life, in which producers and consumers, meeting market goods and services with free competition, reproduce equilibrium in this and the markets in which they were made all the adjustments and adaptations. The idea of economic in the sense of Schumpeter implies a disruption of the balance system of the circular flow in such a way that the introduction of a new combination of materials and production means, that is, from a technological innovation, causes a shift in the production function in the original circular flow, in order to create a new production function that just providing not only the production and sale of new products and processes, but also significant increases in labor productivity are able to provide lower costs, higher revenues and increases profits.

The response to this new innovative entrepreneur expectation of monopoly profit generates, in turn, a sequence of changes in the behavior of economic agents that starts with an expansion of credit, changes in habits and proceeds including, at some point, a wave secondary imitative innovations and improvements (by way of learning by doing or learn using), superimposed on the primary wave caused by the introduction of technological innovation unique to the extent that the expectations of a greater community of businessmen are affected by the evidence and the consequences of destructive nature creative competition between innovators and imitators because during the expansionary phase of the business.

Although Schumpeter (1982) had self confident if the elements of risk and uncertainty inherent in the crucial decision of a technological innovation that has no market at the time of the decision, but it should create a new market for a product innovation or a process innovation production, the project sought to achieve success in the future, yet he underestimated the actual role of rational calculation in the process of decision making crucial. For Schumpeter, the decisions of the innovative entrepreneur are not simply the result of precise mathematical calculations and can not be reduced to these terms, and this theoretical position resembles that of Keynes.

Rosenberg (2006, p. 166-167) points out that there is an additional dimension of radical uncertainty in the decision of the innovative entrepreneur on a specific type of uncertainty is not highlighted by Schumpeter in his emphasis on the discontinuous nature of technological 
innovation. This uncertainty is generated not only by the sequence of technological innovations that may arise in other parts of the economy, but especially those resulting from the further improvement of technology whose introduction is currently being considered.

In fact, the arguments of Schumpeter (1982), when the expected profit is the innovative entrepreneur, gives rise to a presumption that the first innovator reaps the greatest rewards while having a monopoly on innovation. But the crucial decision to undertake an innovation at present can be decisively affected by the expectation that the immediate future can be Significant improvements in innovation intended or expected that another innovation may even arise qualified and replace the first innovation required as soon it is launched.

Therefore it is important to consider the wisdom of the innovative potential entrepreneur to wait the right moment - for her to take the crucial decision to introduce a technological innovation - is reinforced by the observations, available in plenty for all entrepreneurs, as the sad financial fate of countless entrepreneurs that ended in bankruptcy courts because of foolishness and immaturity business to launch a technological innovation prematurely in the face of risk and uncertainty. While innovative entrepreneurs who have success with the introduction of technological innovation can reap high profits until extraordinary entrepreneurs reach the imitators; entrepreneurs impetuous, do not measure the extents of their decisions in the future, may go bankrupt as a result of funding premature investment in technological innovations whose expectations regarding the expected monopoly profits are unpredictable and unworkable in the face of uncertainty about the unknown future.

The expectation of future change may not have the effect of delaying the introduction of technological innovation, but the determination of the main specific features of innovation chosen to compete with other innovations similar or even lower. It is in this sense that oligopolistic competition gets a totally different connotation of perfect competition (free competition without entry barriers), to the extent that the "battles" competition to the powerful "weapon" that happens to be used is the technological innovation that has a power of destruction not only of a single competitor, but an entire industry.

These innovative processes are generators and disseminators of the processes of creative destruction that all companies are subject to the level of capitalist intense oligopolistic competition. In this sense, the Schumpeterian competition, and the oligopolistic nature, acts not only against companies already established in the market, but also against companies that potential entrants are always a real threat ubiquitous. For all this, we must recognize that the process of capitalist development is imminently scalable. 
Revista Economia e Desenvolvimento, v. 25, n. 2, 2013.

When the evolutionary process of the capitalist system is determined by the introduction and diffusion of technological innovations, organizational and financial, its economic and financial impacts together both creative destructive power that cause instability in the economy as a whole, so that the economic system ends up moving between chaos and order without getting into any of these extremes. Therefore, technological innovations, organizational and financial fragility of the financial system of an economy can cause certain disorders that affect the dynamics of capital accumulation and generate business cycles inherent in the capitalist system. [Schumpeter (1984, p. 46-52); Schumpeter (1989, p. 13-20)].

\subsection{The function of the funding for the innovative entrepreneur}

The industrial development based on sustained discontinuous innovations is in principle impossible without bank credit may be able to provide the necessary purchasing innovative entrepreneur. The essential function of credit, therefore, is to provide the innovative entrepreneur of sufficient purchasing power to remove the means of production that he needs their previous jobs, in order to enable a demand for them, and thus drive the economic system for new production channels. Credit granted to the innovative entrepreneur, therefore, can only consist of means of payment created ad hoc lending. It is in this sense that the credit granted to the innovative entrepreneur is essentially new purchasing power for the purpose of transferring it to the entrepreneur, but it does not constitute purchasing power existing either in the form of currency or real assets.

In particular, Schumpeter (1982, p. 74) states: "The creation of purchasing power characterizes, in principle, the method by which the development is carried out in a system of private property and division of labor". In fact, through credit entrepreneurs gain access to mainstream social means of production before they have acquired the normal right to it. The lending accordingly operates as an order for the economic system to accommodate purposes of the innovative entrepreneur, as a command over the means of production it needs, what it means to trust him productive forces.

The credit to the innovative entrepreneur is essential because it is through the power of purchase ("live" money order or cash payment) supplied by the banker that he can have access to all services of natural agents, force labor, capital (machinery and capital equipment), the raw material to be transformed, in exactly the same direction, so that all these requirements mentioned are equally important. This does not mean that there is no material difference between these categories of productive assets. Either way it should be clear that the 
behavior of the innovative entrepreneur is the same for all of these categories, he buys all of them with money, or through which calculates the interest paid, without distinction, are capital goods (machinery and equipment), land (natural resources) or workforce.

Here it must be clear that the meaning of "capital" in Schumpeter is different from the usual concept of neoclassical economists. The capital of an enterprise, according to Schumpeter, is the aggregate of all goods that serve the purposes of the business for the production of other goods, it is the capital (money capital) that faces the world of commodities. The fixed capital goods are purchased with money capital, ie, can purchase the money that was effective as soon as capital invested in the purchase of durable goods. This fact implies the recognition by Schumpeter's importance is the role of money capital in the capitalist system and that money capital is different in terms of physical capital, ie, the fixed capital goods (machinery and equipment) and property working capital (raw materials and secondary) acquired by the innovative entrepreneur.

In the words of Schumpeter (1982, p. 80-81): "The function of real (productive) is to serve a productive purpose that corresponds to their technical nature. The function of capital (money) is to obtain the means for the business (production) to produce it". The capital (money) arises as a third factor that makes a "bridge" between the entrepreneur and the universe innovative means of production it needs to produce new products or production processes. It is clear that the meaning of "capital" in Schumpeter is different from the neoclassical sense of taking capital as a set of capital goods in physical terms.

For Schumpeter (1982, p.81) capital consists of funds purchasing power, ie money (or credit) and other financial assets (which can be converted into cash) to finance innovative investments. It is the realization of technological innovations that money (fiat money current or cashless) and its substitutes financial assets become an essential factor called capital.

\section{FINANCING OF INVESTMENTS IN TECHNOLOGICAL INNOVATION}

The financing of technological innovations by banks has a counterpart, besides the interest rate risks of credit granted by banks to the borrower. For Schumpeter (1982, p. 107), "the interest is a reward for purchasing power by this account of a future purchasing power". The interest rate on loans for productive purposes is found everywhere in the capitalist system, not just where it originates, or in new ventures. The interest paid to bankers as a result of the success of the new venture has its source in profits. The money needed to carry out technological innovation is the key factor in industrial demand in the money market. In this 
Revista Economia e Desenvolvimento, v. 25, n. 2, 2013.

sense, the interest rate is part of the price of purchasing power which is considered as a means of control over productive assets. But the interest is not as income, the direct result of the development in order to be an award for their achievements. Commercial banks and financial institutions are always creating alternative sources of financing of financial innovations.

\subsection{Risk financing of investments in technological innovations}

The innovative entrepreneur is not the agent who assumes the risk of financing. Even when the innovative entrepreneur risks his own reputation, the direct economic responsibility of failure or success does not fall directly on it. Even when the innovative entrepreneur uses its own resources, yet risk is up to him as a capitalist and not in its proper function of innovative businessman. When a potential innovative entrepreneur solves effectively transform your innovation project into reality, he needs purchasing power Banker. It is true that the creation of institutional innovations company to produce a product or production process can provide to its founder anticipated a profit - profit's founder - the real conditions of operating profit from the moment that company created with the support of the innovative financing bank investment, pass to produce and sell their innovations with monopoly profit.

This position is the initial condition for the banker can be convinced of the success of the venture claimed by the innovative entrepreneur. It is true that the profit of the founder applies only to the actual founder of the business (the banker) and not the agent (manager) who sometimes performs the technical task of organizing and leading a public company, but only receives as compensation service run by run, a loud "honorary" as a worker escalated. The realization of innovations requires the funding of investments in industrial innovations so that they can be produced by a company responsible for the manufacturing of technological products and processes. In this sense, no matter if the purchasing power granted by the banker to the entrepreneur is in the form of cash credit or money substitutes.

\subsection{The banker as creator of purchasing power}

According to Schumpeter (1982, p.51-53), the banker is not just a financial agent intermediary of money, form of the purchasing power in the form of fiat money current, but also a creator of money, ie the cash or money order which takes the form of cashless. The banker makes possible the realization of technological innovations in that transfers the charge of purchasing power to the innovative entrepreneur. Financing investments can be as 
innovative external source the money market and / or the capital market. Stocks and financials are also creative ways of credit used to finance technological innovations.

The bank credit supplied from the deposits of customers have coverage, so the creation of fiduciary currency (check) is replaced to validate general acceptance as a means of payment, purchases of capital goods, payments of wages and rents and settlement of contractual debts. When deposits are made into bank loans, usually the businessman who borrows first becomes liable to pay the bank and then becomes your lender. In fact, the first act consists in borrowing by the entrepreneur with the banker, and the second act is to retain deposited in a checking account to make withdrawals when it suits you, the amount of money borrowed to finance banker investment innovation in their own bank lender who is a customer, which means that the banker who funded it can if you want, use portion of the amount of money deposited to make new loans to uncovered bank creating new money.

This is so by the fact that only a small fraction of all business transactions uses material from the current fiat currency, ie, the "live" money in the form of coins or paper currency of the monetary authority. Indeed, the achievements of debt payments and purchases of large volumes of material goods or financial assets among entrepreneurs and sometimes even between consumers and businesses, are usually made by check or by transfer order accounting a checking account to another.

The bill of exchange issued by the manufacturer of goods or the possessor of goods inventories, for example, is sometimes used as a substitute currency. Thus, the producer or host, respectively, after completing and sell their production or spawn and sell your stock of goods, you know against your customers to immediately transform their rights into "money." Here the bill of exchange serves as a temporary replacement for money, as in the case of knowledge of embarkation or disembarkation, and even if the letter is not backed by cash at the time of the transfer, is, instead, based on existing assets recognized in the act the accepted and so, in a sense, as purchasing power.

An entrepreneur can also offer some kind of guarantee you can engage in order to facilitate the granting of bank credit. The entrepreneur can also engage goods purchased with the purchasing power that borrowed from the bank. The pledge is also a type of credit that, at times, people use to solve debt repayment or purchase of goods. However, the redemption of pawned well have validity, which means the risk of loss of wealth (jewelry and framed art rare) or active high monetary value. It thus appears that in real life the total bank credit may be greater than if there were only bank credit covered by deposits. Beyond that bank credit, which arises from the bank's role as an intermediary, for the credit that the bank can provide 
Revista Economia e Desenvolvimento, v. 25, n. 2, 2013.

to your customer that is not covered by deposits, but deposits of medium and long-term deposits or loans themselves received by the entrepreneur as a client of the bank lender.

Stiglitz and Weiss (1992, p. 162-192) emphasize that funding for investment in innovation is high risk by the financing bank, because besides the problems of information asymmetry and risks of adverse selection and moral standing subject the banker, there are also radical uncertainty regarding expected future income prospective project investment in technological innovations borrower's financing.

\subsection{Financial innovation: funding instruments of technological innovation}

No technical and financial innovations, the economic outlook has nothing to offer but a dull and predictable reproduction of goods and services and material means of production that are themselves of a steady state. Innovations in general refer to all types of new developments in the technological, financial and institutional. But the term innovation is also used in particular to denote a technological innovation resulting from the introduction and implementation of new products and new production methods that change the industrial structure as well as the introduction and implementation of new financial instruments that also change the structure financial and are called financial innovations.

In this sense, "the financial innovations of the monetary-financial economy keep resemblance to the technological innovations of typical industrial economy". Minsky (2004, p. 177-200). The process of capital formation is influenced by financial innovations and the use of natural resources depends in part on the availability of technology. Experience has shown that business corporations or financial institutions who discover new products, production methods or financial mechanism does not necessarily benefit the most, since most have their distribution restricted by patents.

\subsubsection{Financial Innovations and their modes}

The concept of financial innovation became known during the 1970s, from the important article author: Silber (1975) and Boissieu (1986). Financial innovation is a new institution that is created by banks or other financial institutions to circumvent the regulations set by the monetary authority. There are at least three types of financial innovations: a) The creation of a new financial asset is not subject to the laws and standards, introduced as a new financial product among the existing portfolio; b) The creation and development of a new financial market that did not yet exist; c) The introduction of electronic methods of payments and receipts that allows streamline and increase the efficiency of banks. 
It is possible to distinguish a new financial product (product innovation) a new method of processing (process innovation) of the inflow and outflow of cash and other financial flows. However, Costa (1993, p. 4-5) points out that there are cases that this cleavage is fine as well, apart from that there are countries which according to the institutional environment promote more product innovations and process innovations other financial activities . For example, the electronic funds transfer serves to illustrate a process innovation, while money market mutual funds represent a new financial instrument, ie, a financial innovation.

The financial innovations are created by financial organizations not only to escape the restrictions imposed by the laws and regulations of a national economy, but also as a powerful tool for attack and defense against established competitors and potential. But that does not prevent retaliation and imitation by competitors. Financial innovations can cause disturbances in the financial market and to disturb the monetary policy actions of the regulator banks.

The duration of economic expansion depends on the demand for investment, and this depends on the conditions in which the financing is offered by financial institutions to entrepreneurs, ie, the facilities created by the banks and financial markets funders. In addition, financial innovations alter the posture of agents as risk aversion. Three recent financial innovations have this role: i) the creation and development of futures markets, options and derivatives, ii) increase the confidence level of investments, and asset securitization by means conversion of capital assets or debt securities in securities.

According to Keynes (1987, p. 322-323), a monetary-financial economy, are these "financial facilities" that largely regulate the rate of new investment and it is this rate of expansion of new investments that determines the level of income and employment. Financial innovations, when successful, allow private banks to obtain a substantial amount of debt of borrowers by creating new institutional channels. Banks are financial institutions that specialize in debt management of its customers in the money market at low cost.

Financial innovations generally produce a new institutional environment in which interest rates on the debts need not rise, even if the central bank to restrict the increase in bank reserves. Nevertheless, the same financial innovations enabling new credits that can avoid recessionary bring with them the "seeds" of the increasing financial fragility, when the borrowers, mostly units are speculative, and this produces a new wave of financial instability that can cause a new wave of economic instability as finance and economy are closely intertwined. (Minsky, 1984, p. 71-89). 


\title{
3.3.2. Convention method and the state of confidence innovation funding
}

In an environment of risk and uncertainty, Keynes (1982, p. 126) emphasized the importance of the convention method when dealt with the state of confidence of businessmen regarding the continuity of stability or instability in their conversion:

\begin{abstract}
In practice, we agree generally to resort to a method that is actually a convention. The essence of this convention - though it does not always work in a way so simple is to assume that the situation of the business will continue indefinitely, unless you have specific reasons to expect a change. This does not mean you actually believe in the indefinite duration of the current state of business. The vast experience teaches that such a hypothesis is very unlikely.
\end{abstract}

A decision to finance the investment is often based on the convention that the current state of the business will remain indefinitely, but really, is hypothesis has been shown false to the facts. In fact, the vast economic experience has shown that this hypothesis is very unlikely in the case of decisions in an environment of uncertainty, as in this case, the expected results of the investment financing ex ante, rarely coincide with the results made ex post. During a boom, the state of confidence of conventional economic agents that guide the decision to finance an investment is the economic growth accompanied by capital gains and revaluations of assets. But when it comes to situations of debt deflation, recession or stagnation, the state of confidence is always conventional built the light of wisdom that debts should be avoided because new debt commitments may take the borrower to bankruptcy.

When a recovery becomes safe and becomes an economic expansion that tends toward full employment, the "prophets" of neoclassical economic future proclaim the end of the instability and the beginning of a new era of prosperity long. So, the economic actors are encouraged to take new loans or financing because monetary and fiscal policies aided by sophisticated theoretical discourses - often supported on empirical results obtained through some econometric model - encouraging the renowned neoclassical economists - begin to convey to members society that crises of debt deflation are things of the distant past. Minsky (1975, p. 128) emphasizes that neither the boom phase of prosperity, not the debt deflation, recession or stagnation nor the recovery or growth with full employment may last indefinitely continued.

In fact, each of these "states" of the economy fed by the internal forces that lead to their own destruction. Of all the existing markets in a monetary production economy, the investment markets and instruments used for the acquisition of shares and control over capital assets are more clearly based on fragile conventions. So it is not surprising that a convention, in absolute view of things so arbitrary, present your weaknesses. But as Keynes warns (1982, p. 127), is the precariousness of the conventional arguments that creates a considerable portion of the contemporary problem of obtaining a volume sufficient financial investment. 
The volume of investments in financial innovations requires introducing the issue of funding in a context cyclical and speculative. Is the financing of investments, often neglected by neoclassical economists, who serves as an important tool damper crisis of financial capitalism, especially when responding to increased public investment in infrastructure.

In an environment of oligopolistic competition, with the presence of powerful business corporations, the technological and organizational innovations are powerful instruments of destruction competitor's actual or the threat of a potential competitor. In designing Heertje (1988, p. 8-9) the interaction between financial innovation and technological and financing of investments in innovation can raise the rate of growth of national economies days that can create and articulate new channels for financing investments in research and development and industrial innovations. Financing investments in innovation always involves risk and uncertainty.

\subsection{Markets for venture capital investor in technological innovations}

Williamson (1991, p. 212-232) reveals that there are two types of mechanism for the allocation of risk capital for innovation: markets and hierarchies. Markets serve mostly smallscale innovations at the beginning stage of the technology life cycle and hierarchies (structure of governance of business corporations) serves the radical innovations of scale in the last phase of the technology life cycle. Due to the economic and technological development in recent decades, small businesses high-tech (high technology) have become an important vehicle creator of technological innovations.

The conditions for long-term financing of technological innovations in the national economy are a reflection of choices made by funding innovative potential. Financing investments in technological innovations is high risk for the lender, since the introduction of any technological subject, beyond the problems of asymmetric information, risk of adverse selection and moral hazard, the radical uncertainty. From the point of view of private financing, a new form of financial support for technological innovations of small businesses is venture capital financing (venture capital).

The venture capital can be defined as the capital of the small company committed to the lender in exchange for its participation in the capital of the company, for the creation and development of small firms specializing in creating new ideas and / or new technology. This participation can be give by buying shares or convertible debentures or not underwritten bonds and other assets. The target funding venture capital investment in technological innovation is the small high-tech company and great potential profitability able to provide to 
Revista Economia e Desenvolvimento, v. 25, n. 2, 2013.

obtain high rates of return in the medium and long term. Authors such as Luna, \& Moreira Gonçalves (2008, p. 234-240) point out that operation with venture capital involves not only information asymmetries and risk of the lender's investment in technological innovation, but also requires synergistic expectations among investors and financiers.

In addition, venture capital funds generally have a predetermined period of existence. At the beginning of the process are defined projects selected and the amount of funding requested. In the third stage, the longest, is the structuring of the financing fund and due compliance with the relevant investment. The last stage is to promote the growth of innovative companies financed and evaluation of different exit possibilities investor.

\subsubsection{Market risk capital for small investors in technological innovations}

Venture capital is not only a resource injection of external funds in a small innovative company is also a required input skills needed by the funding agency, to create a new position of the firm in the market, designing its strategy marketing policy and governance that will prevent waste and increase the profit margin of the innovator. To Prakke $(1988$, p. 86), the small venture succeed, as well as obtaining extra profit from innovative entrepreneur, the gain that the enterprise expects to obtain financing does not come from dividends, as with publicly held corporation, but from capital gains at the time of divestment.

Can distinguish the following categories of risk capital: a) Capital risk individual professional: this is a category of typical hierarchy that consists of individuals, including former individual companies, which have internal funds and expertise to risk their personal fortunes in investing activities of high risk. In addition to this category, the importance of individual vendors and non-professional venture capital - such as families, relatives and friends - should not be underestimated. Nevertheless, the two categories have little power to finance innovations compared with the large specialized financial institutions; b) Funds investment risk of high-tecnology: external funds are formed from cash reserves constitute the largest category of funding of technological innovations in the market for venture capital. These institutional funds are big holders of currency reserves (purchasing power) and financial assets (about money) specially designed to operate in the capital market of high risk. Each innovator is funded by a group of supporters - traditional financial institutions - that come with the monetary resources and for some executive (manager) that receives a commission (fee) on total profits.

c) Corporations financing investment risk of small business: These are financial companies created specifically to finance small businesses in the U.S. which are regulated and licensed by the federal government. These financing companies may require up to three times the 
value of its capital from government agencies, and their role is to provide financial support for the creation and management of small competitive firms;

d) Banks risk investments: These are financial institutions created to fund capital risk of technological innovations of small businesses, including new products or production methods of innovative small. The rapid growth in the number of small businesses innovative hightechnology has encouraged these banks to expand gradually the supply of funding in this area. "In the U.S. this market financing of risk is still relatively small compared to the total volume of financing of corporate investments that nation", Chesnay \& Sauviat (2006, p. 483).

\subsubsection{Venture capital market for the major investor in technological innovations}

Although the firm size is not decisive for the introduction of a technological innovation is of vital interest if the firm has a complementary set of assets in commercial, financial and organizational innovation available for the product or production process. Venture capitalists have provided specialized financial companies to act in interesting capital market risk. Such financial institutions funding venture capital invest their liquid assets - entrusted to his administration by large institutional investors and other large financial organizations - the maintenance of emerging companies with technological innovations and the creation of new companies high innovative power through specific funds whose growth potential is generally derived from the development of cutting edge technologies.

According Viñals \& Berge (1988, p. 158-193) large corporations have expanded their powers of financial leverage in the market risk capital through the creation of financial and organizational innovations, namely: a) Venture capital and financial departments in large corporations: A significant number of industrial groups (large business corporations) have created specialized financial departments as the purpose of meeting the domestic demand for venture capital investment in technological innovations for parts of companies part of the group; b) Venture capital companies and financial subsidiaries of large corporations: Financial firms are subsidiaries of large corporations are created to promote the domestic markets for venture capital, technology and human skills in order to ensure the optimal allocation of resources to high -technology is more flexible, more efficient and more easily reversible. This new fact in large industrial corporations represents a partial replacement of hierarchical coordination mechanisms of management by formal internal market mechanisms formed by industrial companies that make up the economic group, as are typical instances of entrepreneurial giant corporations, like General Electric, Exxon and Xerox.

These financial companies group subsidiaries also finance investment projects of technological innovation from other companies outside the economic group since they are 
relevant to the development and diversification of the technology industry group considered. Such decisions, however, depend on a complex combination of financial and technological strategies in the face of the high risks involved in financing technological innovations.

According Prakke (1988, p. 89-98), the recent trend of several large corporations raise their $\mathrm{R} \& \mathrm{D}$ departments can be seen as belonging to this category of funding capital investment risk with the majority concentrated in the U.S. and Europe. The market risk capital, despite the volatility, has grown in dollar volume, improved the structure of the market supply of risk capital and the quality of these financial institutions.

c) Investment Banking risk of large business corporations: A creation of banks by large industrial corporations is now common practice. Banks and industries can also merge to create financial capital, ie an industrial structure, large financial in which the strategic investment decisions of technological innovations involving venture capital are financially assessed by the bank's economic group. An economic group is formed by parent company (called the holding company) and subsidiary undertakings or subsidiaries that are under the control of the holding company.

This parent company (the holding company) is above all a center of financial decision (a bank), while the companies controlled by the holding company subsidiaries are operating companies of production, transportation, storage and commercialization. "The main role of parent company (holding) in relation to risk capital is financially assess the expected profits of financing decisions on investments in technological innovations or organizational", Serfati (1998, p.141-151). In the U.S.A, for example, financial institutions were gradually replacing the family as shareholders of large business corporations, in order to become major players holding shares of these large companies. Chesnay \& Sauviat (2006, p. 473-478) note that the participation of pension funds and mutual funds in debentures market also increased, but not as much as in the stock market.

\section{CONCLUSION}

Overall, the decisions to fund investments in technological innovations are crucial because they involve risks and uncertainties radical. The economic development of capitalism has always been driven by a fundamental economic force that is the introduction of technological innovation. This process can be observed when separating the routine general industry inserting unique industries that are driven by technological innovations. 
To accomplish the introduction of an innovation, the entrepreneur needs to convince himself of the possibility of success of its technological innovation and also convince the banker to finance innovation intended. The innovative entrepreneur is left with the conduct of a leader with distinct characteristics of political leaders, military, artistic, scientists and managers. The leadership of the innovative entrepreneur comes exactly at the right moment he decides to introduce an innovation in the economic system. The economic leadership of the innovative entrepreneur is very different from leading technical and scientific inventor.

The scientific discoveries and inventions are economically irrelevant, as they do not start in the economic system by the innovative entrepreneur. While entrepreneurs may be inventors as can also be capitalists - are not inventors by nature of their business function but by coincidence and vice versa. Furthermore, innovations, whose realization depends on the innovative entrepreneur, need not necessarily be an invention.

The main difference between discoveries (inventions) conducted in laboratories and research institutions is a technological innovation that only the innovative entrepreneur can decide whether an invention can become an innovation. The realization of an invention is a technical decision of the engineer, while achieving an innovation is an economic decision of the innovative entrepreneur possessing economic leadership. It should be noted that a researcher-inventor has limitations to found a company and market your invention. These activities involve the transfer of the results of the techno-scientific research involving a set of rules on copyright. The research and development departments of large business corporations can develop inventions, even before turning into innovations, they are patented by corporations. In oligopolistic capitalist economy, purchasing power (money) in the form of bank credit (financing) is critical not only for the use which makes innovative entrepreneur performing the purchase of means of production and factors of production, but also because it allows the transfer of ownership of property and assets necessary to introduce technological innovation in the economic system, as even the purchasing power (money) can be transferred.

These large business corporations often devote a portion of retained earnings to finance investments for expansion, diversification and research and development in the search and selection of inventions with the potential of becoming technological innovations. In the current oligopolistic capitalism increasingly technological innovations become automated, more impersonal and less dependent on the leadership of the heroic man of unusual business. The Schumpeterian competition imposed by the corporation business dislodges small and medium enterprise, "expropriates" its owners and finally dislodges the innovative entrepreneur individual social function in capitalist society. 
Revista Economia e Desenvolvimento, v. 25, n. 2, 2013.

A decision to finance the investment is often based on the convention that the current state of the business will remain indefinitely, but really, is hypothesis has been shown false to the facts. In fact, the vast economic experience has shown that this hypothesis is very unlikely in the case of decisions in an environment of uncertainty, as in this case, the expected results of the investment financing ex ante, rarely coincide with the results made ex post. Even so, the decision makers to invest in technological innovations rely on their expectations about the future scenario imagined by them. There is a different kind of innovation that industrial innovation is financial innovation.

Financial innovation is a new capitalist institution that is created by banks or other financial institutions to circumvent the laws and regulations set by the monetary authority. You can distinguish a new financial product (a product innovation) a new method of processing (a process innovation) financial flows in and out. Financial innovations are created by financial organizations not only to escape the restrictions imposed by the laws and regulations of a national economy, but also as a powerful tool for attack and defense against established competitors and potential. But this, however, does not prevent retaliation and imitation by competitors.

There are two classic types of financing investment in technological innovations that are held by venture capital: markets and hierarchies. Markets serve mostly small-scale innovations in the early stages of the life cycle of innovation, and hierarchies serve large-scale innovations in the latter stages. Technological changes of the last stages of the technology life cycle are large-scale and depend on decisions taken within the hierarchies of large industrial corporations. The development of technological strategies for large corporations has created routines for improving the treatment efficiency of seeking funding processes systematic and incremental introduction and diffusion of technological innovation.

The efficiency of capital markets and risk financing mechanisms within the hierarchies operate in a complementary demand for credit by small and large businesses instead of external funds on financial markets. Some countries are more competitive institutions using venture capital, and others using the financial market. Funds to finance investments in technological innovations hierarchies have been threatened by the process of financial globalization.

\section{REFERENCES}

BOISSIEU, Christian. "Quelques reflexions sur l'analyse économique des innovations financières". Economie Appliquée. Tomo 39, n.3. p. 449-472, 1986. 
Financing investment in industrial technological innovation.

COSTA, Fernando Nogueira da. "Inovações financeiras e política monetária". Texto para Discussão, № 9. Campinas, Instituto de Economia/UNICAMP, abril/1993.

CHESNAY, François \& SAUVIAT, Catherine. "O financiamento da inovação tecnológica no contexto atual de acumulação financeira". In: Economia da Inovação Tecnológica. Victor Pelaez \& Tamás Szmrecsányi (Org.). São Paulo, Hucitec/Ordem dos Economistas do Brasil, 2006.

DAVID, P.A. "Clio and the economics of Qwerty". American Economic Review. Vol. 75, $\mathrm{n}^{\circ}$ $5,1985$.

DOSI, Giovanni. Mudança técnica e transformação industrial: A teoria e uma aplicação à indústria dos semicondutores. Campinas, SP, Editora UNICAMP, 2006.

GUIMARÃES, Eduardo Augusto. "Políticas de inovação: financiamentos e incentivos". In: Políticas de Incentivo à Inovação Tecnológica no Brasil. João Alberto de Negri \& Luis C. Kubota (Org.). Brasília, IPEA, 2008.

HEERTJE, Arnold. "Technical and financial innovation". In: Innovation, Tecnology, and Finance. Arnold Heertje (Ed.). New York, Basil Blackwell, 1988.

HELLER, Claudia.“Path-Dependence, Lock-in e Inércia”. Economia da Inovação Tecnológica. Victor Pelaez \& Tamás Szmrecsányi (Org.). SP, Hucitec/Ordem dos Economistas do Brasil, 2006.

KEYNES, John Maynard. A teoria geral do emprego, do juro e da moeda. SP, Atlas, 2009.

LUNDVALL, B.K. (Ed.). National Systems of Innovation: toward a theory of innovation and interactive learning. London, Pinter, 1995.

LUNA, Francisco, Moreira Sérvulo \& Gonçalves, Ada. "Financiamento à inovação". In: Políticas de Incentivo à Inovação Tecnológica no Brasil. João A. de Negri \& Luís C. Kubota (Org.). Brasília, IPEA, 2008.

MINSKY, Hyman P. Can “It” Happen Again? New York, M.E Sharpe, 1984.

MINSKY, Hyman P. Induced investiment and business cycles. Northampton, Eduard Elgar, 2004.

MINSKY, Hyman P. Stabilizing an Unstable Economy. New York, McGraw-Hill, 2008.

PENROSE, Edith. A teoria do crescimento da firma. Campinas, SP, Editora UNICAMP, 2006.

POSSAS, Silvia. Concorrência e competitividade: Notas sobre estratégia e dinâmica seletiva na economia capitalista. São Paulo, Hucitec, 1999. 
POSSAS, Mário. "Concorrência schumpeteriana". In: Economia Industrial: Fundamentos teóricos e práticas no Brasil. David Kupfer \& Lia Hasenclever (Orgs.). Rio de Janeiro, Campus, 2002.

PRAKKE, F. "The Financing of Technical Innovation", In: HEERTJE, A. (Ed.), Innovation, Technology, and Finance , Londres: Basil Blackwell, 1988.

RUTTAN, V. "Usher y Schumpeter en la invención, inovación y el cambio tecnológico".Economia del câmbio tecnológico: Leituras selecionadas por Nathan Rosemberg. México, Fondo de Cultura Económica, 1971.

SCHUMPETER, Joseph Alois. "A instabilidade do capitalismo". In: Economia del câmbio tecnológico: Leituras selecionadas por Nathan Rosemberg. México, Fondo de Cultura Económica, 1971.

SCHUMPETER, Joseph Alois. Teoria do desenvolvimento econômico: Uma investigação sobre lucros, capital, crédito, juro e o ciclo econômico. São Paulo, Abril Cultural, 1982.

SCHUMPETER, Joseph Alois. Capitalismo, Socialismo e Democracia. RJ, Zahar, 1984.

SCHUMPETER, Joseph Alois. Business Cycles: A theoretical, Historical and Statistical analysis of the capitalism process. New York, McGraw-Hill, 1989.

SERFATI, Claude. "O papel ativo dos grupos predominantemente industriais na financeirização da economia”. In: A mundialização financeira: gênese, custos e riscos. François Chesnay (Coord.). SP: Xamã, 1998.

STIGLITZ, J.E. \& WEISS, A. “Assimmetric Information in Credit Markets and Its Implications for Macroeconomics”. Oxford Economic Papers, 44, p. 162-192, 1992.

ROSENBERG, Nathan. "Sobre as expectativas tecnológicas". In: Por dentro da caixa preta: tecnologia e economia. Campinas, SP, Editora Campinas, 2006.

SEN, A. "Addressing global poverty". In: The World in 2002. London, UK, The economist, p. $50,2001$.

SILBER, W. "Toward a theory of financial innovation. In: Financial Innovation. W. Silber (Edit.). D.C. Heath, Lexiton, 1975.

USHER, A. P. "Cambio técnico y formação de capital". Economia del câmbio tecnológico: Leituras selecionadas por Nathan Rosemberg. México, Fondo de Cultura Económica, 1971.

WILLIAMSON, Oliver E. Mercados y Jerarquías: su análisis y sus implicaciones antitrust. México, Fondo de Cultura Económica, 1991. 